Gerencsér Péter

\title{
Civil a felvevógéppel. A certeau-i taktika kisajátítása a vlogokban és a civil újságírásban
}

\begin{abstract}
Absztrakt
A tanulmány Michel de Certeau-nak a hatalmi struktúrákat a mindennapi átlagember részérôl kicselezô „taktika” fogalmát alkalmazza a web 2.0-es közegre. Két, webkettes kommunikációs forma, a vlog (videoblog) és a civil újságírás tanulmányozásán keresztül arra a következtetésre jut, hogy a kereskedelmi és a politikai érdekek megfordították a „mindennapi élet praktikáinak” Certeau által leírt logikáját.
\end{abstract}

\section{Szerzó}

Gerencsér Péter 2017-ben szerzett doktori fokozatot a Szegedi Tudományegyetem Irodalomtudományi Iskolájában. Kutatási területei: internetes múvészet, újmédia, cseh/szlovák film, közép-európai animációs film.

E-mail: gerencser77@gmail.com

https://doi.org/10.31176/apertura.2019.14.2.4 


\section{Gerencsér Péter}

\section{Civil a felvevoogéppel. A certeau-i taktika kisajátítása a vlogokban és a civil újságírásban}

\section{Taktikai stratégiák}

Klasszikus munkájában Michel de Certeau határozott kritikával illeti a tömegkultúra azon elméleteit, melyek passzívnak tételezik a fogyasztókat, ehelyett ô a hatalmi struktúrák potenciális bomlasztóit látja bennük. Könyve, $A$ cselekvés múvészete az átlagemberek olyan mindennapi praktikáira fókuszál, mint a bolyongás térbeli gyakorlatai, az emlékezet asszociatív múködése, a konyhamúvészet, a fusizás vagy a diákrajz az iskolai tankönyvben. A francia filozófus ezek vizsgálatával megkérdőjelezi azokat az állításokat, melyek a fogyasztót a hatalomnak alávetett szótlan szubjektumként gondolják el, és amellett érvel, hogy a hétköznapi gyakorlatok gyakorta kijátsszák a hatalmi viszonyokat. Azáltal, hogy a szerző a civileknek ezeket a praktikáit „fegyelemellenesnek” nevezi (Certeau 2010: 15), tudatosan szegül szembe Michel Foucault „fegyelmezô társadalom” fogalmával (Foucault 1990: 285-308.), amely szerint a fegyelmezés módozataiban a „hatalom mikrofizikája” érvényesül. Certeau különbséget tesz a hatalmat gyakorlók „stratégiái” és a hatalmat kijátszók „taktikái” között: a „taktikát [...] a hatalom hiánya határozza meg, mint ahogyan a stratégiát egy hatalom posztulálása szervezi” (Certeau 2010: 63). A stratégia az ő fogalmi rendszerében az erôseket, a hatalom cselekvôit jellemzi, akik saját „hellyel” (intézményekkel, vállalatokkal, hadsereggel, apparátussal stb.) rendelkeznek. Ezzel szemben a taktika a gyengéket írja le, akiknek nincsenek saját helyeik, ezért külsô erôforrásokra kénytelenek támaszkodni. Ổk a domináns csatornákat használják és sajátítják ki, hogy marginális pozícióból képesek legyenek fogyasztó helyett termelôként viselkedni. Ilyenformán a „taktika helye a másik helye" (Certeau 2010: 19), ahol leleményessége révén az átlagember kicselezi a készen kapott struktúrákat, melyek egyúttal aszimmetrikus hatalmi viszonyokat is jelölnek. Jóllehet a francia filozófia „mindennapi” ethoszához hasonlóan Certeau szövege kevésbé nevezhetô diszkurzívnak, hemzseg a nehezen megszelídíthetố metaforikus nyelvhasználattól, a szerzô a „taktikát” lényegében olyan parazita tevékenységként írja körül, mely egy meglévô rendszert belülrôl forgat fel, így a gyengék „húzhatnak hasznot más szabályok követéséből, ezzel második szintet hoznak létre az elsô szinten belül is" (Certeau 2010: 56).

Noha Certeau a mindennapok szubverzív gyakorlatait az „offline”, fizikai világban tanulmányozta, a „stratégiának” és a „taktikának” a katonai terminológiából származó szembeállítása meglátásom szerint hatékonyan kamatoztatható a webkettes jelenségeknél is. A certeau-i elmélet efféle 
aktualizálása (vagy stílszerúen: kisajátítása) nem nélkülözi az elôzményeket. Az elmélet

alkalmazásának az offline világtól az online világ felé való elmozdulását már önmagában is tanúsítja Henry Jenkins életmúve, aki az analóg rajongói kultúra vizsgálatától fordult az internetes „részvételi kultúra” felé. 1992-ben megjelent könyvének (Jenkins 1992) címében (Textual poachers) a „szövegvadorzás” fogalmát is Certeau-tól orozta, aki szerint a „mindennapiság a vadorzás ezernyi formájából származik" (Certeau 2010: 12). A Certeau-féle ellentétpárt hasznosították újra az internetes múvészet egyik speciális területén, a „taktikai médiában” is, amely az ellenzéki politikai médiaaktivizmus (a vírus, a médiahack, az információs túlterhelés) és az esztétika kapcsolatát jelöli (vö. Garcia - Lovink 1997; Joanne 2002), és amelynek imperatívusza szerint „a prédának vadásszá kell válnia” (Garcia - Lovink 1997). Kimondottan a web 2.0-re alkalmazva frissítette fel a „taktika” fogalmát Lev Manovich, amikor azt állította, hogy a „stratégiák és taktikák ma már gyakran szorosan összekapcsolódnak valamilyen interaktív viszonyban, és jellemzôik gyakran felcserélôdnek" (Manovich 2011).

Ebben a tanulmányban bizonyos szempontból Manovich-nak a stratégiák taktikaivá válására, a taktikai stratégiákra vonatkozó állítását igyekszem továbbgondolni és konkretizálni két webkettes mozgóképes formában, a videoblogokban és a civil videó-újságírásban. Korábban amellett érveltem, hogy bár a web 2.0 elsődleges ideológiája a demokráciával azonosnak vélt demokratikus struktúrák kiterjesztése volt, a nem hierarchikus és a hierarchikus szerveződések párhuzamos módon épültek ki. ${ }^{[1]}$ Ezt a kettôsséget az alábbiakban a vlog és a civil újságírás példáján a decentralizáció és a centralizáció logikai ívét követve fejtem ki, és azt állítom, hogy a hatalmi viszonyok újratermelôdése a Certeau-féle „taktika” fogalmának megfordításaként ragadható meg. Amíg a vlogok esetében ennek a szubverziónak kereskedelmi, a civil újságírás taktikáit használó fake newes esetében annak politikai oldalát emelem ki, miközben a két kommunikációs forma cselei között szoros taktikai összefüggést látok.

\section{A taktika kifordítása 1.0: A kereskedelmi televíziózás újratermelódése a vlogokban}

\section{A televiziós m?fajok remedializációja a YouTube-on}

Aligha vitatható, hogy a videomegosztó portálok a webkettes mozgóképkultúra egyik domináns formáját képezik. Ezeknek az oldalaknak a használatmódja láthatóan Oidipusz-komplexussal reflektál a televízióra, megismételve a „régi” és „új” kommunikációs eszközök közötti kölcsönös rivalizálást, mely a festészet és fénykép, a regény és a film, a film és a televízió, a televízió és a videó stb. viszonyában többször megismétlődött már a médiatörténetben. Nevezetesen: miközben a videomegosztó portálokat a televízió alternatívájaként értelmezik, azok retorikája arról árulkodik, hogy a korábban megszületett médium folytonos viszonyítási alap. A legnépszerúbb szolgáltatás, a YouTube már elnevezésével, a képcsô (tube) személyre szabásával (you) is a televízió privatizálásának vágyát hordozza, ahogyan korábban az 1960-as évek videomúvészete is a tömeges 
elektronikus képtovábbítás (a televízió) személyes csatornává való átalakítását túzte zászlajára (Dorfles 1983: 4). Innen nézve az internetes videomegosztás az elitista és avantgárd videomúvészeti alkotások mindennapivá válásának tủnik, azzal a nem elhanyagolható különbséggel, hogy utóbbi a fizikai világ és a médiamúvészet extrém határpontjait is kutatta. A YouTube esetében a televízióhoz fúződő ambivalens viszonyt tanúsítja maga a „csatorna” elnevezés, valamint a szolgáltatás korábbi szlogenje, a „Broadcast yourself!”. Szimbolikus, hogy ugyanez az ellentmondásos viszony tapasztalható a Youtube-ra 2005. április 25-én feltöltött legelsô videó esetében.

A Me at the Zoo címú felvételen a YouTube egyik alapítója, Jawed Karim a San Diegói állatkertben az elefántok kerítése elôtt benyomásairól beszél. A felvétel medialitása visszautal azokra a házi videókra, melyek elkészítéséhez már a Super 8-as film 1965-ös bevezetése a Kodak által, majd a VHS videokazetták 1975-ös piacra dobása és a képmagnók ugyanattól az évtizedtôl kezdôdô elérhetôvé válása után adottak voltak a technikai-gazdasági feltételek, nevezetesen a nagyközönség számára is olcsón hozzáférhetô kamerák, tároló- és lejátszóeszközök, hiányzott azonban egy döntô tényezô, a nyilvános terjesztés lehetôsége. Ezért ezeknek a házi videóknak a széles körú terjesztéséhez a televízió segítségét vették igénybe, ahol megadott músoridôben, hivatásos szerkesztốk (kapuôrök) válogatásában kerülhettek csak képernyőre. Az internetes videomegosztás mindennapos gyakorlattá válása megoldotta a hozzáférésnek ezt a problémáját, a bemutatás nem függ músorpolitikai-kereskedelmi elvektôl, idôtényezôtốl (ezek on demand, azaz bármikor megtekinthető „tartalmak”), ehelyett olyan globális terjesztés vált lehetôvé, melyekról az elektronikus jeleknek antennákkal történő felerôsítése, a PAL, SECAM és NTSC analóg televíziós rendszerek között lavírozó szabványok, de akár a múholdas músorszórás idején csak álmodhattak. Ugyanakkor ez a 19 másodperces elsô videó elôre is vetítette a YouTube késôbbi ismérveit, mint amilyen a(z) - „me” névmással jelölt - önreprezentáció uralkodóvá válása, melyet az elektronikus (de nem digitális) videó kapcsán nevezetes esszéjében Rosalind Krauss „videonárcizmusként” írt le (Krauss 1983: 46-51.). Ugyancsak elôremutatott az eredetileg a webkamera nézốpontjából származó, a nézôi figyelmet a beszélô arcára koncentráló facecam plánozás felé, amely a vlogok (videoblogok) képkivágási sztenderdjévé vált. Alyssa Fisher és Louisa Ha 2018-as statisztikai kimutatása szerint a legnépszerúbb Youtube-videók között a videoklip, a korábban a televízióban már vetített músorok, majd a filmek, a hírek, a „csináld magad” videók, a dokumentumfilmek, a háziállatokról szóló videók, a termékbemutatás és az útirajz szerepel (részletes számadatokkal lásd: Fisher és Ha 2018: 37). Mindezek azt mutatják, hogy a YouTube kezdettól fogva privatizált televíziózásként írható le.

Amellett, hogy a videomegosztás az intézményesített médiavállalatok alternatíváját nyújtotta, számos alakzata a már létrejött televíziós múfajok puszta digitális terjesztése vagy utánzata volt. A YouTube saját, kevert szempontú kategóriarendszere (zene, sport, játék, filmek, élô, $360^{\circ}$-os videó stb.) kevésbé veszi figyelembe a „régi” médiumokból importált és a kimondottan weben kialakult, „bennszülött” múfajok közötti különbségeket. Ez a gyakorlatias múfaji térkép végsô soron éppúgy kereskedelmi alapú, a közönséggel való kapcsolattartásra épül, mint a korai filmé, melyrôl Tom 
Gunning azt állította, hogy másfajta felosztást alkalmaz, mint a múfajok szigorúan elméleti megközelítése, mivel a „marketing és a gyártás során [...] intenzíven pragmatikus, célelvú döntést hoznak a kategória használatáról” (Gunning 2004: 280). Magam a YouTube-videók három nagyobb csoportba rendezését javaslom aszerint, hogy mennyiben függetlenednek a televíziós mintától: (1) importált, (2) hibrid, (3) privatizált.

(1) Az elsóbe tartoznak az importált múfajok, mint az illegális vagy legális módon - 2010-ig 10 perces idôkorlátban, így feldarabolva - feltöltött filmek, a videoklipek, a spotok, a trailerek és teaserek, a házi videók örökségéből származó cicás / kutyás (vagy általában állatokkal kapcsolatos) videók, a szintén innen honosított bakik és átverések (bloopers és prank video), késóbb pedig (2013 májusától a hitelesített felhasználóknak engedélyezve) a televíziózás mintáját megöröklő élő közvetítések (live streaming).

(2) A televíziós músorszórástól való elmozdulást mutatja a hibridnek nevezhetô második típus, a digitális technológia nem hierarchikus szerveződését, vagyis az internet adatbázis-logikáját (Manovich 2009) kiaknázó compilation és best of videók, a jármúvek múszerfalára felszerelt, a kamera által rögzített képet mutató, virtuális utazást biztosító dashcam videók (ennek elôzménye a slow television, bár ez a tévében inkább experimentális), a flashimation (flash animáció), a remixek, a kapuôrök hiányát szabadszájúsággal kiaknázó paródiavideók és az internet virális természetét felhasználó mémvideók.

(3) A harmadik típusba a privatizált televíziózás formái tartoznak, melyeknek vezetô múfaja a vlog. A téma, a terjedelem, a forma sokrétúsége okán nehezen definiálható vlogokat végsô soron a személyesség és a szubjektív megszólalás abroncsolja össze, amint azt eredeti elnevezése, a hajónaplózásra utaló log, a belóle származó blog (weblog) és az annak mintájára megalkotott vlog (videoblog) sejteti. Tekintettel arra, hogy a vlog kategóriájába tartozó (egy)személyes músorszolgáltatások függetlenek a tartalomtól, az alábbi csoportosítási kísérlet heterogén, de talán nem önkényes rendezóelvet alkalmaz. A múfaj naplószerú eredetét leginkább az egyéni életutakat fragmentált feljegyzések sorozataként bemutató személyes vlogok konzerválták. Mellettük elôszeretettel használt múfaj a termékbemutató, a paródia (comedy), a videojátékokat minôsítő vagy azokat végigjátszó gaming és gameplay vlog, az oktatási célokat szolgáló tutorial és how-to videó, a vásárolt / beszerzett termékeket értékelô zsákmányvideó (haul video), a kérdezz / felelek ( $Q \mho A$ ), az eredetileg az Amazon e-kereskedelmi gyakorlatából származó, a kicsomagolt küldemény meglepetésére építô unboxing videó, a kihívás (challenge video), a csináld magad videó (DIY), a kritika, a tematikai alapon elkülöníthetô vlogok (a televíziós magazinok örökségét is magukon viselô gasztrovlog, utazási, számítástechnikai, állatos, autós és politikai vlog). A youtuberek piacosítására szakosodott Mediaklix marketingügynökség jelentése szerint 2018-ban a tíz legnépszerúbb kategória sorrendben a termékkritika, a hogyan kell videó, a személyes vlog, a játékbemutató, a paródia, a zsákmányvideó, a mémek, a best of adatbázis, az oktatóvideók és az unboxing volt. ${ }^{[2]}$

A múfaj(bokor) elnevezésének a naplózásra visszamenô konnotációja ugródeszkaként használható 
fel annak vizsgálatához, hogyan remedializálja a vlog a kereskedelmi televíziózást. Amennyiben a napló múfaja az idôközönként egymásra következố személyes bejegyzések sorozatát jelöli, melyet eredeti értelme szerint nem a nyilvánosság elé szánnak, a vlog az azonnali (vagy közel azonnali) publicitással és a globális hozzáférhetôséggel írja felül ezt a definíciót. A nyilvánosság és a periodikus frissítés a befogadóban várakozást teremt a folytatásokra. A televízióban „cliffhangernek” nevezett narratív megoldás egyértelmúen a 19. századi nyomtatott sajtótermékekben meghonosodott, folytatásokban megjelenô tárcaregények szeriális elbeszélésmódjára emlékeztet, melyet a televízió a 20. század második felétól az epizodikus szappanoperákban és a koherens narratív építkezésre törekvő teleregényekben folytatott. A televíziós sorozatok narratív szerkezetét kutató Sarah Kozloff azt állítja, hogy ezeket a folytatásos sorozatokat nemcsak a történet és az elbeszélés szintjén, hanem az egyéni napirendet strukturáló músorrend szempontjából is szükséges vizsgálni (Kozloff 2010: 7-38.). Amíg azonban a hagyományos televíziósorozat arra készteti nézôjét, hogy a nap vagy a hét elôre meghatározott idôszakában beütemezett program szerint üljön le a képernyô elé, addig a felfüggesztett sorozat logikáját folytató videoblog az on-demand technológiából következően tetszôleges idôpontban teszi lehetôvé az új részek megtekintését, melynek feltöltésérôl a nézó a csatornára való feliratkozással értesítést is kaphat. A vloggerek tekintélyes része ennek függvényében kevésbé törekszik arra, hogy ritmikusan, pontos menetrend szerint ugyanazokon a napokon töltsön fel új músort, mint ahogyan az a televíziós sorozatoknál kialakult. Bár ellenkezô példát is találunk erre, mint amilyen Szirmai Gergely többnyire filmkritikákra szakosodott HollywoodNeresAgency nevú vlogja. Ám éppen az ô példája mutatja azt is, hogy egészségügyi problémái miatt elmaradozó feltöltései a nézôk körében olyan elvonási tüneteket gerjesztettek, ami a nézői várakozások kielégítetlenségéből fakadt (ehhez lásd az 5. lábjegyzetet). Ez azért lényegbevágó, mert a hétköznapi youtuber a népszerúség növekedésével olyan kényszernek van kitéve, amely a fordista sorozatgyártás irányába mutat, korlátozza személyes és alkotói szabadságát, és gazdasági érdekekből a televíziós logikát kénytelen követni. Hangsúlyozom, itt én nem a hagyományos televízió és az internet házasságáról, a „konvergens televíziózásról” beszélek (errôl Csigó 2009), hanem az attól szervezetileg különálló gyakorlatokról, amikor azt állítom, hogy a vlog nem a televízió alternatívája lesz, hanem annak mintázatát folytatja.

\section{Az alulról épitkezés kicselezése}

A fentiekből következik, hogy a népszerúség fenntartása és növelése újabb és újabb „tartalmak” folyamatos elkészítését és feltöltését követeli, így nemcsak a videokészítésben ezáltal jártasságot szerző, profivá váló amatôr és a hivatásos közötti határvonal mosódik el óhatatlanul, hanem az adott vlog piaci gyarmatosítása (szponzorációja) szintén a kereskedelmi televízió üzleti modelljének alkalmazását követeli meg. Mindez olyan csapdahelyzetet állít elô, melyben a nézôi várakozás generálása újabb videó elkészítését sürgeti, az új videó előállításának idóigényessége és financiális költségei viszont a gazdasági partnerekkel való kapcsolatok kiépítését hozhatja magával, melyek viszont elvárásaik révén (például milyen módon és hányszor szerepeljen az adott termék neve a „mûsorban”) korlátozzák az alkotói kreativitást, végsô soron megkülönböztethetetlenné 
téve ezeket a munkákat a médiacégek ipari logikájától. Ennek következtében nemcsak az amatôr „tartalom-előállítás” web 2.0-es ideája van bukásra ítélve, hanem ezek az alkotók álcivilként az amatôrség álarcában csapják be nézóiket (ahogyan a televízióban a valóság-show elnevezés implikációi). Amíg Certeau a másik „helyének” használatát a gyengékhez kötötte, most az erôsek alkalmazzák ezt a taktikát. Nem önmagában a profizmus megjelenése jelenti a problémát, hanem az, hogy nincsenek meg azok a világos kritériumok, melyek alapján különbség tehetô a civil, laikus alkotó és a vállalati szereplô „tartalma” között, mert utóbbiak az elóbbiek taktikáját alkalmazzák ProAm (profi és amatốr) hibridként. ${ }^{[3]}$ Ugyanerre a gyarmatosító logikára hívta fel a figyelmet a Flash-intrók és a YouTube-on kivirágzó Flash-animációk esetében is Michael S. Daubs. A Flash eredetileg kimondottan a webre tervezett, interaktív, a nagyközönség animációkészítési lehetôségeit megkönnyítô szoftveres alkalmazás volt, ám Daubs szerint maga a televízió kezdte magához idomítani a Flash-esztétikát, veszélyeztetve annak szubverzív lehetôségeit (Daubs 2010: 51). Megismétlódik az a fajta alapmozgás, amely számos régi és új médium, például a színház és a film viszonyában lezajlott: az új médiummal szembeni kezdeti ellenállás helyét az inkorporáció (a kisajátítás) veszi át, márpedig Certeau a kisajátítást nem a hatalmat birtoklók stratégiájaként, hanem a gyengék taktikájaként jelölte meg.

Beszédes, hogy ezt az astroturfingre emlékeztetô marketing-technikát - amely az alulról építkezés maszkjával fedi el a mögöttes szponzorációt vagy a vállalati irányítást - már az egyik legelsô YouTube-sztár, a lonelygirl15 esetében is alkalmazták. A hétköznapiság álarcában tetszelgô vlog 2006-tól kezdôdôen egy Bree névre hallgató tinédzserlány mindennapjaira összpontosított a YouTube-on. A vlog mögött azonban egy gondosan megtervezett stáb állt, a lányt egy hivatásos, de értelemszerúen kevésbé ismert színésznô, Jessica Rose játszotta el, a történeteket professzionális forgatókönyvíró írta, míg az egész megtévesztô projektet a Creative Arts Agency nevú cég keretezte (Burgess és Green 2009: 95. Gender-szempontból kimondottan erre a példára koncentrálva: Hall 2015: 128-142.). Az énreprezentáció tehát fiktív alapokon nyugvó szemfényvesztố hoax volt, mely az amatôrség látszatával tévesztette meg nézôit. A hitelesként tálalt közvetlenség mesterségességére már évtizedekkel korábban játékosan kérdezett rá Hajas Tibor Öndivatbemutató (1976) címú filmjében, amikor az autentikus inautentikusságot vizsgálta. Az imitált amatôrséget a médiacégek az elsô, YouTube-on világhírúvé vált énekes, Justin Bieber esetében is alkalmazták, akinek imázsát, miszerint self-made-manként, médiaipari támogatás nélkül emelkedett fel, maga a menedzsment terjesztette. Bevett piaci fogás, amikor a hirdetôk azzal igyekeznek termékeiket a célközönséghez eljuttatni, hogy a népszerú vloggerek kezébe ingyenesen drága mobileszközöket adnak, akik aztán hatásos akció keretében tönkreteszik azokat a mûsoraikban. Elsô látásra ezek a tettek a tinédzserek szélsôséges, ámde spontánnak tûnô szabadidôs gyakorlatainak tûnnek, sok esetben azonban olyan bujtatott reklámok, melyekben számítástechnikai cégek a Z-nemzedéket megcélozva a szokatlanság és a szenzáció elvével alkalmaznak generációs marketinget. Ezek a példák jól mutatják a certeau-i taktika önmaga ellentétébe fordulását, vagyis azt, hogy a termékké váló vlogok egy része az alulról szervezôdést visszafordítja fentrốl lefelé irányuló modellre. Nagy visszhangot váltott ki Magyarországon egy népszerú vlogger, Szabyest hasonló vagy hasonlónak tûnô esete, aki a kihívás-videók („Úgysem 
mered!") címszava alatt egy gondosan bepanírozott iPhone-készüléket rántott ki forró olajban (a videó 2019 elejére már nem volt elérhetô). Kérdés, mennyiben volt ez spontán és mennyiben megtervezett. A vlogger azonban kivívta kortársai ellenszenvét, akik több esetben rejtett szponzorációs technikáival vádolták ôt (lásd a rengeteg reakcióvideót). ${ }^{[4]}$ Mindazonáltal az alkotó utóbb hagyományos televíziós reklámban is feltûnt, egy internetes videóban pedig egy üdítôs palackot turmixolt le, amit nem a saját, hanem az üdítócég YouTube-csatornája hozott nyilvánosságra.

A magát MaxMoeFoe múvésznéven hirdetô ausztrál vlogger videói szélsôséges módon önveszélyes testi reakciókra épülnek. A nézői érdeklődés felkeltése érdekében provokatív múveinek egyfajta vízjele a szándékosan elôidézett hányás, melyet nagy mennyiségú alkohol, más folyadék (ételfestékkel színezett tej) vagy a nyálkahártyát irritáló élelmiszerek (fahéj) tömeges mennyiségú elfogyasztása idéz elô. A fizikai sokk miatt MaxMoeFoe fiókját a Google az iránymutatások megszegése miatt több esetben letiltotta, és egyes videóinak megtekintését a nézônek csak a saját fiókjába való bejelentkezése után teszi lehetôvé. Ez a fajta megbotránkoztatás sok szempontból a történeti avantgárd, kiváltképpen a dada örököse, amit Walter Benjamin sokkhatásnak nevezett, és filmbeli megjelenését a dadaizmusból eredeztette: „Ezen alapul a film sokkhatása, mely mint minden sokkhatás, fokozott lélekjelenléttel ragadható meg. A fizikai sokkhatást, melyet a dadaizmus még valamiféle morális sokkhatásba csomagolt, a film technikai struktúrájánál fogva szabadította ki ebból a burokból" [kiemelés az eredetiben] (Benjamin 2003). Amíg a sokkhatás a történeti avantgárd esetében esztétikai tényező volt, itt a figyelemorientált nézôség „szabadította ki ebból a burokból”. A tömegesedés ugyanakkor meg is foszthatja a provokációt attól, ami: a provokációtól.

A népszerúség utáni hajsza ugyancsak a profitorientált televíziók nézettségi kimutatásokra épülô módszerében találja meg saját elôzményeit. A népszerúséghez az érdeklődés tömeges fenntartása szükséges, ami pedig a közönség lehetôség szerinti kiszélesítését feltételezi. A népszerúség azonban elkerülhetetlenül leegyszerúsítéssel jár. Megfigyelhetô ez már Petőfi Sándor költészeti taktikájánál is, akinek pályafutását Margócsy István úttörô módon vette górcsố alá a marketing „irodalmi gépezete” felól (Margócsy 1999: 48-74.). Az amerikai múvészettörténész, Clement Greenberg a kétségtelenül elitista Avantgárd és giccs címú esszéjében (Greenberg 1978: 93-103., Greenberg 1986: 109-118.) azt állította, hogy a magaskultúrához tartozó avantgárddal ellentétben a tömegkultúrának szükségszerúen a giccs az osztályrésze, így hatalomátvétele óhatatlanul a kultúra elsilányosodásához vezet. Greenberg talán túlságosan is abszolutizál, tézisét úgy fogalmaznám át, hogy a népszerûségen alapuló tömegkultúra - pontosan a befogadói kör kiszélesítése miatt hajlamosabb a giccsre, a mézeskalács és a hútômágnes esztétikájára. Ez a logika érvényesül abban, hogy a nem rétegigényeket kielégítô szappanoperák tartalmát a minél nagyobb nézettség érdekében úgy szabják meg - még ha ezt a médiacégek igyekeznek is titokban tartani -, hogy az a nem túl szofisztikált igényekkel rendelkező közönség számára is érthetô, befogadható legyen. Nos, a vlogok esetében, úgy vélem, újratermelôdött az a modell, amely behatárolja az ismertséget fenntartani igyekvő youtuber lehetôségeit, aki nem foglalkozhat kényes, intenzív nézői 
koncentrációt igénylô vagy megosztó témákkal, fôként, ha kereskedelmi érdekeltség (szponzor) és/vagy monetáris kényszer (ebból tartja el magát) tartja féken. Ilyenformán a kapuôrök mintái visszaszivárognak. Az anyagi javakká konvertálható nézettségi tôke - és kivált a YouTubecsatornára való feliratkozók száma miatti piaci nyomás - a tömeges elvárásoknak való alárendelódés felé tereli az alkotókat. Legutóbb épp ezt fogalmazta meg a vlogger Szirmay Gergely:

Énnekem egy célom volt a feliratkozószámmal. Én egyszer az életemben én akartam lenni a legtöbb feliratkozószámú Magyarországon. Ez megtörtént, tartott szerintem 10-11 napig, [...] és akkor bejelentettem mindenkinek, hogy mostantól ezzel nem foglalkozom. Én úgy gondolom, hogy az embernek a tartalmát borzasztóan kizsigereli, hogy ha feliratkozószámot akar elérni: egyszerúsíti a nyelvet, egyszerúsíti a humort, popularizálja a témákat [...]. [5]

A népszerúségi maxima következménye a vlogok tekintélyes részének standardizációja és homogenizálódása, ami szembemegy a web 2.0 plurális világokat ígérô ideológiáival. A „long tail” csak azt teszi lehetôvé, hogy ugyanabból az áruházból választhassuk ki a különbözôsége ellenére hasonló logikát múködtetô terméket. Ahelyett, hogy a laikus kreativitás felemelkedése sokszínú, változatos világokat hozna létre, a közismertség érdekében a már biztonságos, bejáratott formátumok variációit, remake-jeit hozzák létre. Ilyennek kell tekintenünk az ugyanazokra a forgatókönyvekre épülô unboxing- és kihívás-videókat, ami egyszersmind a szúkebb közösségbe való befogadás rituális beavatási szertartása. Mindezek a vonások a sztárságot hajhászó youtuberek videóit - melyek, hangsúlyozni szükséges, korántsem fedik le a vlogoszféra teljes spektrumát egymáshoz nagyon hasonlóvá, szabványosított produkcióvá teszik. A közelkép (facecam-plánozás) és a televíziós bemondót imitáló „beszélő fejes” technika mellett ugyancsak bevett mise-en-scène a videoblogok esetében, hogy a háttérben hálószoba vagy valamilyen intim környezet látható. Ez a mód Roosevelt elnök Fireside chats (Kandalló melletti csevegések) címú rádióbeszélgetéseinek és az amerikai talkshow-k mintáját követve a magánbeszélgetés közvetlenségét, a hétköznapiság imázsát igyekszik vizuálisan megteremteni. A bejáratott stílusokra és formátumokra, ezáltal pedig biztonsági játékra épülô taktikák az alapvetôen hollywoodi gyökerú ipari méretû filmgyártás logikájából és a kereskedelmi televíziók gyakorlatából fakadnak. A film esetében a párhuzam a többszörösen tesztelt, panelekból építkezô, egymáshoz rendkívül hasonló narratív felépítésben, a sztárrendszerben és a kasszasikerek megismétlésének vágyában mutatható ki. A televízió esetében pedig a külföldi músorlicencek megvásárlásában, vagyis abban, hogy a televízió-társaságok az egyéni kreativitást megspórolva a már sikeressé vált recepteket domesztikálják. Adorno és Horkheimer a „kultúripar” múködését a standardizációval írta körül, amit az ipari termelésbôl vezettek le: „Milliók részvétele a kultúriparban, úgymond, kikényszeríti a reprodukciós eljárásokat, amelyek viszont elháríthatatlanná teszik, hogy a számtalan helyen jelentkezô azonos szükségleteket szabványárukkal elégítsék ki” (Horkheimer - Adorno 1990: 154). A fentiek tükrében a vlog-kultúra populáris része nemhogy a televízió alternatíváját nem kínálja, hanem egyenesen 
annak üzleti modelljei, felülrôl lefelé irányuló szervezôdése köszön vissza a web 2.0-es platformokban. Hangsúlyozom, itt nem - pontosabban: elsôsorban nem - arra utalok, hogy a televíziós intézmények afféle „konvergens média” keretében kiterjesztik a befolyásukat a vlogokra, hanem arra, hogy a vlogokban a televíziós mûsorkészítés - standardizációs - logikája jelenik meg, ami két különböző dolog. Az interneten a „You” helyett az alkotás a sztárrendszer által inspirált hírnév és az üzleti érdekek egymást kölcsönösen erôsítô kettôse felé tolódott el.

\section{A YouTube-forradalom felfalja gyermekeit}

A piaci igények kiszolgálásának igénye megtorpedózza az internet ideológiájával szorosan összekapcsolódó egyenlőségelvet, a javakhoz való hozzáférés demokratikus ideáját is. Mert az internet technikai szempontból ugyan valóban rizomatikus módon szerveződik (vagyis kevésbé épül alá-fölérendeltségi viszonyokra), üzleti és kulturális szempontból viszont újratermeli a hatalmi egyenlôtlenségeket. Másként fogalmazva: a demokratikus struktúrák önmagukban nem demokrata struktúrák, azaz nem vezetnek automatikusan demokráciához.

Már az a tény, hogy a vloggerek szponzorációjánál a hirdetôk szempontjából a vízválasztót a profizmus jelenti, megkérdójelezi a web 2.0-es alkotófolyamat civil, laikus jellegét, virtuális osztályok szintjén újratermeli a különbségek politikai gazdaságtanát. A profizmus ugyanis ebben az esetben nem az alkotás esztétikai profizmusát, hanem a technikai színvonalat, vagyis a videokészítés felszereltségének minôségét jelöli (HD-minőség, okostelefon, profi kamera és mikrofon, állványzat, vágás és képmanipuláció). Márpedig aki szegény, az a legszegényebb, mert az esélyei is csökkennek a mobilitás lehetôségére. Az egyenlőtlenségek fenntartásához hozzájárul a Google / YouTube hirdetéspolitikai rendszere is, amely ugyan számos tényezôből, bonyolult nem is nyilvános - algoritmusok alapján tevôdik össze, de egyik jellegzetes mérôszáma az összehasonlításokat a matematikai számok nyelvére lefordító CPT. A CPT (Cost Per Thousand) az egyes videók ezer megtekintése után járó hirdetési költséget jelenti, ugyanakkor a nyelv döntô kritérium, mert a hirdetôk angol nyelvû videók esetében jóval többet hajlandók fizetni, mint például egy magyar nyelvú esetében. Ez afelé tereli az alkotókat, hogy a kulturális-nyelvi sokszínúség helyett minden értelemben a lingua franca irányába mozduljanak el. Persze a reklámmegjelenítés a YouTube-videók monetizációjának csak egyik aspektusát jelenti, a másik két legfontosabb elem a szponzoráció (partnerkapcsolat) és - bizonyos népszerúségi kritériumok elérése után - a merchandise-termékek eladásából befolyt összeg. Ugyanakkor azok a nagy feliratkozószámmal rendelkezô vloggerek, akiket fôként a Z-generációra gyakorolt befolyásuk miatt az „influencer” divatszavával címkéznek fel, az offline világban való részvételük folytán (növekvố meghívások, workshopok, díjátadók, televíziós részvételek, reklámfilmes szereplések) még nagyobb bevételi lehetôségekhez jutnak, és a folyamat önmagát gerjeszti.

Ennek gazdaságtanát érdemes a kapcsolati rendszereket, többek között a sikerfaktorokat kutató hálózatelmélet transzdiszciplináris módszertana felôl röviden megvilágítani. Miközben ugyanis az internet technikai szerkezete nem preferálja a középpontokat és a hierarchiákat, társadalmi értelemben az összekapcsolások és csomópontok már nem múködnek ennyire „demokratikus” 
módon, amire elég triviális példa a Google keresômotor rangsorolási módja és a keresôoldal kezdôlapként való beállítása számos böngészốben. A világháló látszólag egyenrangú, hipertextuális világában a hivatkozások túlnyomó része csak nagyon kis számú oldalra és tartalomra mutat. A hálózatelmélet a világháló esetében az úgynevezett Pareto-féle közgazdaságtani modellt hasznosította újra, mely szerint a termelésbôl és a szolgáltatásokból származó bevételek 80\%-a a népességnek csak egy kis töredékéhez, körülbelül 20\%-ához kerül. Barabási-Albert László vizsgálata szerint ez az internet kapcsolódási hálózatát tekintve is érvényes, vagyis „a web hivatkozásainak 80 százaléka a weboldalaknak csupán 15 százalékára mutat” (Barabási-Albert 2016: 137). Ebból tehát nemcsak az következik, hogy a szegény a legszegényebb, hanem az is, hogy a gazdag még gazdagabb lesz, ismét sutba dobva a web 2.0 szép reményeit. A YouTube-forradalom felfalta gyermekeit.

Miközben azonban a standardizáció és azok gazdasági modellje a vlogoszféra jelentôs részét jellemzi, figyelembe kell venni, hogy léteznek más, de a kutatásokban kevésbé reprezentált múködésmódok is. Henry Jenkins többek között a vlogok leginkább látható részét eluraló monetizáció miatt megkülönbözteti egymástól a web 2.0-t és a részvételi kultúrát, elôbbit elüzletiesedettnek, utóbbit tisztán laikusnak tételezve (Jenkins 2010). Nem veszi azonban figyelembe, hogy a részt terjeszti ki az egészre: leszúkíti a web 2.0-t a kereskedelmileg bekebelezett, irányított „tartalmakra” és a fiatalabb nemzedékekre. A fentiekben felvázolt, a kereskedelmi televíziózás mintáját követố standardizációs logika azonban nem általánosítható a vlogoszféra egészére, csak éppen az internetes diskurzus természete folytán ezek láthatósága a legnagyobb. Rajtuk kívül - jóval kisebb hírverést csapva - a rövid formáktól a civil televíziózásig számos egyéb forma létezik, melyek érdeklődési körök függvényében szólítanak meg csoportkultúrákat, és egyúttal építenek fel közösségeket. Burgess és Green a televíziós Oprah-show webkettes kiterjesztésének sikertelenségét az intimitás és a közönséggel való dialógus korlátozottságával magyarázza (Burgess és Green 2009: 103). A megfigyelésbôl azt vezetik le, hogy nem az amatôr / profi, a felülrôl szervezett / alulról szerveződô, piaci / nem piaci közötti dichotómia a döntô eleme a vlogoszféra megértésének, hanem a közönséggel való kapcsolattartás módja:

A kulcsfontosságú elemzôi megkülönböztetés inkább attól függ, hogy a tartalom-előállítók mennyiben értelmezik a YouTube-ot részvételi médiumként, és mennyiben múködtetik felelôsségteljes és elôrelátó módon, ahelyett hogy valahonnan máshonnan próbálnának meg tartalmi és tapasztalati modelleket importálni. (Burgess és Green 2009: 104)

A médiacégek vagy a velük összeolvadó ProAm tartalmak mellett megkülönböztethetünk nonprofit szervezôdéseket és egyéneket, akik nem irányított anyagokat töltenek fel, hanem valóban „fabrikálnak” (Certeau 2010: 12), amatôr „felhasználó generálta tartalmat” barkácsolnak, és céljaik között nem szerepel vagy másodlagos az anyagi haszonszerzés. Róluk nem beszél Jenkins, amikor a web 2.0-t kizárólag üzletinek minôsíti. SanskritFritz például fejkamerájával napi rendszerességgel pásztázza az autósok biciklisekkel kapcsolatos közlekedési morálját, „csináld magad” videóinak 
kerékpáros közönsége hálózatot alkot. Az európai városok villamoshálózataira fókuszáló Niskopodtogowiec csatorna professzionális színvonalú, de civil mozgóképei legfeljebb közösségi finanszírozásra támaszkodhatnak.

A WebKispap néven futó debreceni görögkeleti lelkész a teológiai kérdések szórakoztató formában történô oktatását tüzte ki célul. A szatirikus humora és információgazdagsága miatt kedvelt Cobranco kerékpáros útirajzai úgy szólítják meg a nézôközönséget, hogy kikerülik a kattintásvadászatot. A jelenleg (2018 novemberében) 321000 feliratkozószámnál járó és egyes videoklipjeivel többmilliós nézôszámot produkáló rapper, Essemm úgy emelkedett fel egy kapuvári garázsprojektből a magyar hip-hop szcéna élére, hogy teljesen megkerülte a hagyományos terjesztési csatornákat és marketingeszközöket, underground szerepból mára lényegében a zenei szubkultúra domináns figurájává vált.

Az „indie-knek” ezek a kiragadott példái azt jelzik, hogy egyes gyakorlatok továbbra is megmaradtak a profitorientált televíziózás alternatívájaként, de nekik jóval kisebb figyelmet szentelt a tudományos kutatás. Jenkins homogenizáló állításával szemben tehát a web 2.0 nem azonosítható a kereskedelmi média új formájával, az üzleti, az autonóm és a non-profit modellek egymás mellett, párhuzamosan léteznek. Így aztán nem az az állításom, hogy a videoblogok egésze, hanem annak egy része - civilként indulva és/vagy a civilség álarcában - újratermelte a kereskedelmi televíziózás logikáját. Az amatôrként tálalt, valójában azonban irányított vlogoknak ezeknek a megtévesztô cselei a Certeau által leírt taktikát belülrôl sajátítják ki, mert azt az erôsek oldalán alkalmazzák, ezzel pedig a feje tetejére állítják.

\section{A taktika kifordítása 2.0: a mindennapi politika praktikái a hírgyártásban}

9/11 civil reprezentációjának ellentétes tendenciái

Szimbolikus, hogy a bipoláris világrend összeomlása utáni fukuyamai szép új világ illúziójának összeroppanásától kezdve a debord-i spektákulumon át a Baudrillard-féle szimulákrumig sokféle szempontból vízválasztónak számító 9/11 (erről korábban: Gerencsér 2014: 16-31.) egyszerre tekinthetô a civil újságírás és az álhírek mérföldkövének is. A civil újságírásnak sokféle kezdôpontját lehet kijelölni, kezdve a vertovi kameraszemtől (kinoglaz) a cinéma vérité aktivizmusán és a direct cinema fly-on-the-wall (légy a falon) technikáján át a romániai médiaforradalomig (amikor az élő közvetítés során hétköznapi emberek vették át a hatalmat a diktatúra televíziójában), a Rodney King videóig (amely közvetlen katalizátora volt az 1992-es Los Angeles-i fekete lázadásoknak), a Monica Lewinsky és Bill Clinton afférját 1998. január 17-én elsôként megszellôztetố személyes blog, a Drudge Report honlapjáig, sốt a Landerer nyomdagépét elkobzó 1848-as pesti radikális ellenzékig. Ugyanakkor kétségtelen, vagy nem, hogy a 2001. szeptember 11-én lezajlott terrortámadások laikus beszámolói megágyazták a talajt a civil újságírás azon módjainak, melyek aztán a 2004-es kelet-ázsiai cunami civil videóriportjaiban, a 2010-11-es 
Arab Tavasz YouTube-forradalmában vagy a Wall Streeten 2011-ben tábort vert Occupy mozgalom több nézôpontból történô mobiltelefonos közvetítésében bontakoztak ki.

A Világkereskedelmi Központ elleni elsô támadást, az északi toronyba beleszálló utasszállító repülógép becsapódását ugyanis tudomásom szerint csak egyetlen videofelvétel örökítette meg. A mozgóképet nem hivatásos újságíró, hanem egy túzoltócsapat munkatársa készítette, akinek felvételét utóbb lejátszották az esemény rögzítésérôl lemaradó televíziók is. A videó nemcsak egy civil (értsd: az újságírói szakmában civil) felvételnek az intézményesült médiára gyakorolt hatását tekintve mérföldkô, hanem abban is, hogy a televíziónak köszönhetôen alighanem ez a civil videó büszkélkedhet az egyik legtöbb megtekintéssel a világon. Az első gép rombolását megörökítő mozgókép készítôje hirtelen az ikertornyok felé fordítja a kameráját, sốt amikor megtörténik a becsapódás, még rá is közelít a toronyra. Ahelyett, hogy csupán saját szemével tekintette volna meg az eseményt, kameráját rögtön a történések irányába fordította, így a katasztrófa civil szemtanúsága hirtelen újságírói magatartássá vált, mert az eseményt mások számára is rögzíteni kívánta.

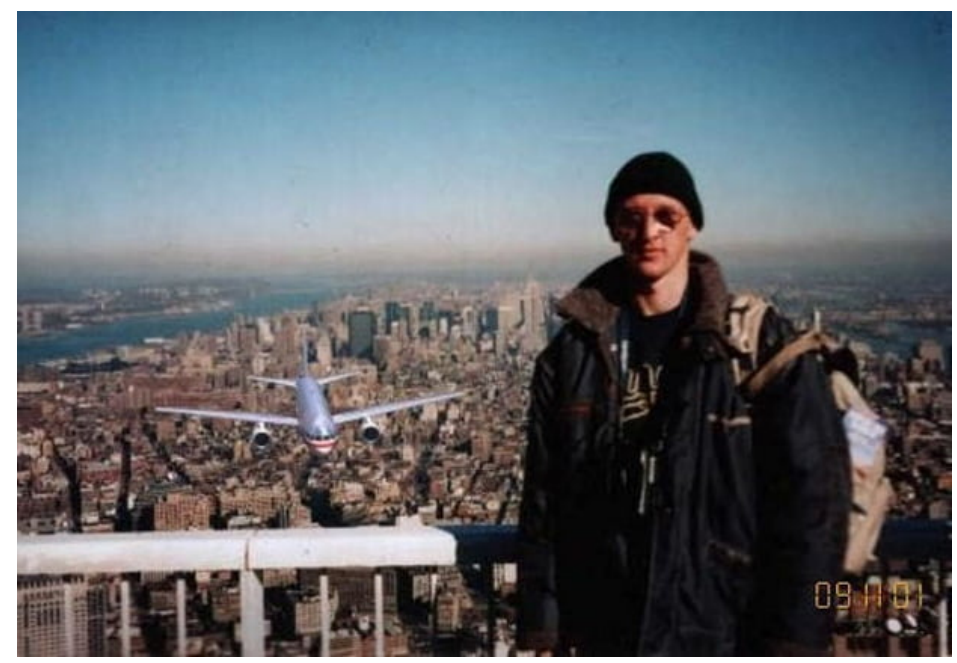

Tourist guy

Ugyanakkor a civil újságírás efféle felemelkedésével párhuzamosan szinte azonnal megjelentek a 9/11-es hoaxok, melyeket a web 2.0-es szolgáltatások éppen akkoriban növekvô kulturális jelentôsége gyorsított fel (errôl részletesebben írtam: Gerencsér 2003: 46-60.). Egy ideig hitelesnek tûnt az a fotó, mely a „World Trade Center utolsó turistája”, „Waldo” vagy egyszerúen „Tourist guy” néven híresült el. A fotón sapkával és hátizsákkal egy fiatalember látható a WTC tetején, miközben mögötte a repülőgép közeledik. Mint azt 2001 novemberében az Index nevú magyar hírportál hivatásos újságírói kiderítették, amit aztán a Wired, a legbefolyásosabbnak tartott amerikai „geek” magazin is átvett, a felvétel egy magyar turistát ábrázol, aki nem 2001. szeptember 11-én, hanem 1997-ben járt a WTC-ben, és az eredetileg viccnek szánt kép egy brazil üzletember révén hódította meg egy nap alatt a világsajtót és a netet (a hoax leleplezôdéséhez részletesen: Cattani 2001, Brenner 2001). A hiperreális fotó nemcsak a digitálisan manipulált fénykép dokumentatív erejére és a civil hírgyártásra, hanem ezzel összefüggésben a fake news-ra, 
a webkettes terjeszthetôség gyorsaságára és az ellenôrizetlenül átvett források késôbb „churnalism” néven elhíresült felhasználására is rámutatott (Johnston és Forde 2017: 943-946.), melyek a 2016-os amerikai elnökválasztás idején értek tetôpontjukra a Facebookon történô megoszthatóság politikai jelentôségével. Összességében tehát $9 / 11$ olyan, a web 2.0 által katalizált mediális fordulópont volt, amely egyszerre mutatta meg a civil újságírás és az álhírgyártás két ellentétes oldalát.

\section{A civil újságírás apóriái}

A civil újságírás (citizen journalism), és azon belül a civil video-újságírás, a hírközlés olyan új módja, melynek során a civilek újságírói eszközöket használnak a tájékoztatáshoz. A web 2.0 a hírszolgáltatásban a hétköznapi emberek tömeges részvételét tette lehetôvé, vagy ahogyan a baloldali naiv idealizmus felmelegítésével röviden utalni szoktak rá: hangot adott a hangtalannak. A belpolitikát sikeresen befolyásoló dél-koreai civil híroldal, az OhmyNews beszédes módon az „Every Citizen is a Reporter” mottót választotta magának. Én magam nem annyira a civil újságíró, mint inkább a civil újságírói magatartás elnevezés felé hajlok, mivel kevésbé újfajta foglalkozástípusról, inkább a civilek ideiglenes szerepérôl van szó. Ha készítünk egy listát a civil újságírás alternatív elnevezéseibôl, mint amilyen a közösségi, az állampolgári, a részvételi, a gerilla, az utcai, a partizán, az amatốr, az alulról szerveződô (grassroots) és az alternatív újságírás, a körülírások látható módon egy irányba konvergálnak. A címkék a web 2.0-t körülvevô ideológiákat visszhangozzák (ehhez lásd: Gerencsér 2019), ilyenformán a civil újságírás tankönyvszerúen az újságírás webkettes formája. Az eredeti eszménykép szerint a politikai pártok érdekeinek kiszolgálójaként és a kereskedelmi érdekek foglyaként tételezett nagy médiavállalatok hivatásos újságírásával szemben jöttek létre, melyek a kritika szerint elhanyagolják a marginalizált csoportokat, manipulálják a híreket, a tájékoztatást az infotainment jegyében szórakoztatássá változtatják és elhallgatnak bizonyos témákat.

A gyakran e negatív identifikáció („mi nem olyanok vagyunk”) által definiált civil újságírás ideológiája az amatốr szerepek hangsúlyozásával kimondva-kimondatlanul az elveszett hitelességet, ôszinteséget és az „ôrkutya” funkciót (az ellenôrzést) igyekszik visszaszerezni, és olyan témákat is a fókuszpontba kíván emelni, melyek a hivatásos újságírás vakfoltjaira esnek. Ezekkel a szerepekkel a függetlenséget, az üzleti kiszolgáltatottság hiányát, illetve az ezekből következő újságírói szabadságot kapcsolják össze (Riaz 2011: 114-115., 121). A civil újságírásnak a professzionálissal szembeni másik elônyösnek tartott tulajdonsága a szemtanúság, nevezetesen az, hogy a hivatásos sajtót megelốzve, az események közvetlen közelében személyesen is jelen van (mint a WTC elleni elsô gép támadása esetében), vagy egyenesen annak részvevőjeként mutathatja be a történéseket (mint a 2011-es Tahrír téri tüntetések idején). A civil újságírás afféle „breaking news-ként" a véletlen vagy tudatos jelenlét révén közelebb áll az események centrumához, gyorsasága, jelenléte és hitelessége összehasonlíthatatlanul elônyösebb a profival szemben. Saqib Riaz szerint a civil újságírás ezért a diktatúrákkal szembeni harc hatékony eszköze lehet (Riaz 2011: 116).

A WTC-nek nekiütközố elsô repülógépet még csak egyetlen civil kamera vette fel, ezzel szemben a 
három évvel késôbbi indiai-óceáni cunamit számos résztvevô és áldozat mobiltelefonja rögzítette. Bár ezeket a videókat nem professzionális újságírók készítették, a terjesztés továbbra is döntôen hagyományos csatornákon (televíziós híradásokban) történt. 2013. április 15-én a bostoni maratoni futóversenyen elkövetett robbantásos merényletnél az $\mathrm{ABC}$ híradása döntôen az amatôrök által készített mozgógépeket mutatta be, melyeket hivatásos újságírók és szakértôk kommentáltak, rámutatva a civil és profi újságírás együttmúködésére, ahol az egyik a másikat feltételezi.

A 2011-es Occupy mozgalom és különösen a rendôri erőszak elleni 2014-es fergusoni zavargások idején viszont a civilek kikerülték a hírközlés formális csatornáit, és azokkal szembehelyezkedve alternatív módon terjesztették a mozgóképeket, a számos kamera nézôpontok sokaságát tette lehetôvé. A gerilla-újságírás szerepe döntôen mutatkozott meg a 2011-es Arab Tavasz során, amikor a civilek nemcsak hogy nem használ(hat)ták a cenzúrázott televíziókat, hanem a diktatúrák meghosszabbított kezeinek tekintve ôket egyenesen azokkal szemben definiálták magukat. A web 2.0 politikai használatának áttörését jelzik a felkelések alternatív elnevezései: a tunéziai események a Twitter-forradalom vagy WikiLeaks-forradalom, az egyiptomi felkelés a Facebook-forradalom, a szíriai polgárháború pedig a YouTube-forradalom címkét kapta. A népfelkeléseket mediális aspektusból vizsgáló Sahar Khamis szerint az internetnek ezt a fokozott szerepét ironikus módon maguknak az arab államoknak az autoriter irányítása tette lehetóvé (Khamis 2013: 55-59.). Állítása szerint a diktátorok államaik infrastrukturális elmaradottságát, oktatási rendszereik csökevényeit az internetes hálózat fejlesztésével igyekeztek kompenzálni, ami a gazdaság reorganizálását is szolgálta. Nem számoltak azonban azzal, hogy az internet a terjesztési csatornákat is pluralisztikussá teszi, ami adott esetben ellenük is fordulhat. Khamis szerint a feltöltött vagy az AlArabiya televízióhoz eljuttatott mobiltelefonos videók és a közösségi média kapcsolattartási lehetôségei nemcsak tájékoztatási, hanem mobilizációs eszközként is funkcionáltak, mivel a szervezôdést és a kommunikációt is megkönnyítették. Ezt ő az internet politikai használatára utalva „kiberaktivizmusnak” nevezi. Khamis állítását továbbgondolva ezek a videók valóban katalizátori szerepet játszottak, amire beszédes bizonyíték, hogy Egyiptomban a Tahrír térre 2011. január 28-ra meghirdetett tömegdemonstráció, a „Harag péntekje” idején a Mubarak-rezsim az egész országban lekapcsolta a teljes internet- és a mobiltelefon-szolgáltatást. Azok visszaállítása után a Facebookon meghirdetett „A Milliók menete” közvetlenül vezetett Hoszní Mubarak egyiptomi diktátor február 11-én bekövetkezô lemondásához. Tunéziában szintén hozzájárult a szervezôdéshez Hamada Ben Amor (El General) rapénekes YouTube-on terjesztett videója, [6] mely politikai aktivizmusra buzdított. Mivel a hip-hop alapvetôen az utcára vonuló fiatal generációkat szólította meg, a forradalom himnuszává váló rap végsô soron olyan publicisztikai szerepet töltött be, mint az 1848-as európai események „forradalmi versei”. [7] Azok a videók, melyek Tunéziától Szíriáig felkerültek a webkettes platformokra a vertovi filmszem ideológiáján alapuló, de Jean Rouch gyakorlatából eredô antropológiai filmkészítés „résztvevő megfigyelés” módszerét írták újra, melyben észrevehetô a videokészítô közvetlen megfigyelése, voyeurista technikája, de egyúttal szubjektivitása és aktivizmusa is.

A civil újságírásnak ez a gyakran aktivista jellege átvezet az egyik apóriához, az elfogultság 
problémájához. Nevezetesen ahhoz, hogy mivel a civil hírközlők sokszor nem kívülállók, hanem az események résztvevôi, valamelyik politikai álláspont elkötelezett hívei közül kerülnek ki, és éppúgy hajlamosak az eseményeket kizárólagosan egyes szemszögekból bemutatni, mint azok, melyek ellen létrejöttek. Ennek másik példája az az ív, amit a WikiLeaks és geekként induló atyja, Julian Assange a hacktivizmustól önmaga paródiájáig leírt. Az információszabadságot zászlajára tûző 2006-os alapítású szervezet a kiszivárogtatáson nyugvó hacker-újságírás és a nagy mennyiségú szerkesztetlen hírre épüloo adatújságírás olyan úttörô kombinációját teremtette meg, amely korábban elképzelhetetlennek túnt. A döntôen titkos kormányzati anyagok nyilvánosságra hozatalával operáló szervezet, amely Dávid és Góliát mesebeli harcának újraírásával teremtette meg a kisember azonosulási lehetôségét, a hadifoglyokkal szembeni kínzásokat leleplezó Guantanamo-kézikönyvtôl és az elefántcsontparti kormányzat korrupciós ügyeitôl kezdve a mobiltelefonok kormányzati lehallgatását Edward Snowden által megszellôztetô iratokig és az Irakban állomásozó amerikai hadsereg visszaéléséig számos leleplezô dokumentumot szivárogtatott ki. Részrehajló volt azonban már a 2007. július 12-ei bagdadi mészárlásról készült videó tálalása is, melyet Chelsea (akkor még: Bradley) Manning „Lady Gaga” feliratú CD-n küldött a WikiLeaksnek. A Collateral Murder néven nyilvánosságra hozott felvétel címe pártos, értelmezett, ${ }^{[8]}$ a képek pedig hatásvadász módon George Orwell-idézetekkel és az események tendenciózus értelmezésével vannak ellátva. A WikiLeaks a személyes adatok védelmét több ízben figyelmen kívül hagyta, így veszélybe sodort emberéleteket. Mindezek alapján felmerül a kérdés, üdvözítô-e a teljes transzparencia, van-e határa a titkos információ kiszivárogtatásának. Miközben Julian Assange az információszabadság hívének szerepében tetszelgett, szervezetének finanszírozási módjai és kapcsolati hálózatai átláthatatlanok maradtak, a demokrata párt vezette amerikai kormányzattal való konfliktusa pedig sokak szerint a titkos orosz állami machinációkkal való kokettálásra sarkallhatta. ${ }^{[9]}$ Ezek a kérdések nemcsak azt vetik fel ismét, hogy mennyire falta fel a webkettô forradalma saját jakobinusait, hanem rávilágítanak a civil újságírás menetrendszerúen felszínre kerülô paradoxonára is, hogy a társadalmi felelôsségvállalás eszméjével a civilek végső soron olyan aktivisták, akik érdekelt félként léphetnek fel, amint azt a Collateral Murder elôre megképzett interpretációs kontextusa mutatja.

Ez az elfogultság vezet át a másik apóriához, a valószínúsíthetô tapasztalatlansághoz és mesterségbeli megbízhatatlansághoz, vagyis ahhoz, hogy amatôr múvelôi révén a gerilla videoújságírás szinte szükségszerúen kerül konfliktusba a szakértelemmel, a sajtó szakmai szabályaival, aminek folytán a civil újságírás csak alkalmi tevékenység lehet. Tófalvy Tamás a nyomtatott sajtó újságíróinak az online hírportálok iránti ellenszenvébôl vezeti le, hogy az amatôr és a profi közötti különbség nem médiatechnológiai, hanem kulturális ellentét, amire a „határtárgy” fogalmát használja, amikor is saját érdekeik mentén maguk az újságírók húzzák meg az újságírás és a nem újságírás, az amatôr és a profi, a komoly és a bulvár közötti határokat (Tófalvy 2017: 68-70.). Az Arab Tavasz vagy az Occupy példái élesen világítottak rá az információs monopóliumok megszúnésére, ami ahhoz a konklúzióhoz vezethet, hogy ha egyenrangúnak tekinthetô a decentralizált nyilvánosság és a mainstream sajtó szerepe, az utóbbira nincs is szükség. Ha ugyanis azt állítjuk, hogy a civil újságírás is képes arra, amire a hivatásos, akkor a formális logika szabályai 
szerint egyúttal azt is állítjuk, hogy az újságíráshoz nincs szükség szaktudásra. Ha viszont képzettek, máris profik. Másfelól amennyiben az újságírás tartós tevékenységként stabilizálódik, múvelóje egyre inkább átkerül a civil / hivatásos közötti választóvonal túlsó oldalára. Aligha lehet például azt állítani, hogy a már intézményesült WikiLeaks továbbra is laikus és outsider maradt. Felszámolódik a határ amatôr és profi között, ami újratermeli azokat a politikai és kereskedelmi kényszereket, melyekkel a hagyományos újságírás szembesülni kényszerül.

Ebből fakad a harmadik apória, mivel a folyamatos hírközlés kényszere olyan versenyhelyzetet teremt, amelynek során a korábbi amatốr profivá válva újraalkotja az amatốr - profi ellentétet. Gyakorta blogok emelkednek fel mainstream pozícióba, vagy a médiavállalatok és politikai ágensek hoznak létre taktikusan blogposztokat. Ahogyan az elsô részben tárgyalt vlogok a nagyobb megtekintésszám érdekében hajlamosak a standardizálódásra, úgy financiális fenntartása érdekében a civil sajtó hajlamos a szenzáció irányába eltolódni. Összességében ugyanaz a nyomás helyezôdik a civil újságírásra, mint amit Pierre Bourdieu a televíziós újságírás kapcsán kifejtett, vagyis hogy a piaci kényszer, a nézettségi kritérium miatt fennáll a veszélye, hogy alávesse magát a befogadói elvárásnak: „a hireknek a termelésére szakosodott mezó specifikus logikájában az olvasók kegyeiért folytatott verseny könnyen az elsóbbségért, a legeslegfrissebb hírekért (a szenzációért) folytatott versengés formáját öltheti - persze annál inkább, minél közelebb vagyunk a piaci "pólushoz«” (Bourdieu 2011: 108). Amikor Michael Kunczik azt állítja, hogy „ellenôrizni vagy csökkenteni kell a kereskedelmi érdekek befolyását”, az állami beavatkozások mellett szintén a gazdasági szempontok elhatalmasodását állítja szembe a „demokratikus” sajtóval (Kunczik 2001: 21). A 22-es csapdája abban jelentkezik, hogy a professzionalizódáshoz financiális alapok szükségesek, amely múködôképes gazdasági modellt, így kompromisszumokat feltételez. Az üzletipolitikai érdekek miatti kompromisszumoktól pedig a civil újságírás esetében is egyenes út vezet az intézményesülésnek azokhoz a korlátaihoz, melyek a profi újságírást szorítják. Végsô soron ez a civil újságírás legfóbb paradoxona.

\section{A sárga újságírás álcivil taktikái}

Ettôl a gazdasági kényszertôl pedig már csak céljaiban különbözik a szintén szenzációra épülô, elốzményeit a 19. századi sárga újságírásban (yellow journalism) megtaláló álhíreknek (fake newes) az a fajta logikája, amely utóbb a 2016-os amerikai elnökválasztási kampány és annak gyakorlati politikai hatása révén került a médiatudományi érdeklődés homlokterébe. A civil újságírásnak a hozzá kapcsolt hitelességi tényezóben van a legnagyobb ereje, ám a civilek álarcába bújtatott propagandisták, a „posztigazság” (post-truth) hírvivői éppen a hitelességet torpedózzák meg, azt használják ki, fordítják önmaga ellentétébe. Michel de Certeau az idegen helyek használatát még a gyengékhez kötötte, most viszont az erôsek használják az idegen helyeket, civilként tüntetve fel magukat.

Mivel a hírnek meglehetôsen képlékeny a definíciója, ha egyáltalán lehetséges, nem világos, hogy mi alapján tehetố különbség hír és álhír között. A fent említett példánál maradva, az a mód, ahogyan a WikiLeaks Collateral Murder címmel közzétette a bagdadi mészárlásról szóló videót, a 
névadással, az idézetekkel és a feliratokkal már manipulálta az eredeti felvételt, így kérdés, vajon milyen fokig tartozik az álhírek közé. Allcott és Gentzkow mára a téma egyik elsôdleges hivatkozásává vált tanulmányukban az álhírt úgy definiálják, mint „torzított jeleket, melyek nem korrelálnak az igazsággal”, utóbb pedig hozzáteszik, hogy „olyan újságcikkek, melyek szándékosan és igazolhatóan hamisak, és olvasóikat félre tudják vezetni” (Allcott és Gentzkow 2017: 212., 214). Köszönjük szépen, de ki dönti el, mi az, hogy torzítás? Honnan ismerhetjük fel a szándékot? Mi az, hogy igazolhatóság, pláne mi az, hogy igazság? Ezek nem egyszerúen eldönthetô kérdések, csak az értelmezés nyújthat - ingatag - fogódzót. Allcott és Gentzkow nem azért érdemlik meg busásan az iróniát, mert nem határozzák meg pontosan, mi az álhír, hanem éppen ellenkezóleg: mert naivan azt gondolják, hogy pontosan meghatározható.

Azok, akik az álhírgyártásban apokalipszist vizionálva új formát látnak, nem számolnak azzal, hogy álhírek mindig is léteztek, korábban sem voltak igazán „tények”, a dezinformáció ôsidôk óta a háború folytatása más eszközökkel. A valósághajlítás múvészete sem a Donald Trump körüli agytröszt vagy az orosz propaganda 21. századi találmánya, amint azt gyakorta felületesen állítják. Elôzményei az elmúlt száz évben olyan tevékenységekhez köthetôk, mint a náciknak a Holokausztra vonatkozó eufemisztikus nyelve (rakomány, végső megoldás, különleges bánásmód, zuhanyzó), a riefenstahli propagandafilmek, vagy a Vöröskeresztet megtévesztô, a terezíni gyújtôtábor álvalóságáról készült $A$ város, melyet Hitler a zsidóknak adott (Der Führer schenkt den Juden eine Stadt, 1944) címú film, melynek zsidó rendezôjét, Kurt Gerront rögtön a forgatás után Auschwitzba deportálták. Az Ál-Dmitrijekben dúskáló és II. Katalin óta a Patyomkin-falvakban bővelkedô Oroszország Szovjetunióvá átalakulva a film politikai jelentôségének lenini hangsúlyozásával, a mediatizált kirakatperekkel, a G. B. Shaw-t is becserkészô hiperreális világokkal olyan mesteri szintre emelte a megtévesztést, hogy Mihail Epstejn félig ironikusan azt állítja, hogy a posztmodernizmushoz kapcsolt szimulákrumot a szovjetek már jóval a Nyugat Jean Baudrillard által leírt esszéje elốtt kiterjedt mértékben alkalmazták (Epstejn 2001: 5-69.). Nyilván a kiragadott példák heterogének, de éppen közös nevezőjük, a szimuláció taktikája bizonyítja, hogy a fake news a közfelfogással szemben nem újdonság, nem a web 2.0 találmánya. 
Ma a szenzációra, az emócióra és a drámaiságra épülő álhírek terjedéséhez azokat az eszközöket használják fel és sajátítják ki, melyek a web 2.0 utópiái szerint a civil kreativitáshoz (a „felhasználó elóállította tartalom”) tartoznak. Ahogyan a náci propagandaminiszter, Joseph Goebbels azt állította, hogy a szórakoztató propaganda a legjobb propaganda, továbbá hogy az a legjobb propaganda, melyről nem látszik, hogy propaganda, ${ }^{[10]}$ nos, a 2010-es években a már meglévô struktúrákba parazitaként befurakodva, magukat mémeknek álcázva, az ellesett pillanatokat digitálisan manipulálva és a marketingeszközöket (vírus- és gerillamarketing, célzott hirdetés) politikai célokra használva popularizálják az álhíreket. Ez végsố soron fonákja a „mindennapi élet” Certeau által leírt civil „praktikáinak”. Mert amíg Certeau szerint a „gyengéknek szüntelenülidegen erőforrásból kell hasznot húznia” (Certeau 2010: 19), a webkettô esetében a politikahasználja a civilség és az amatôrség látszatát, a meglévô struktúrákba trójai falóként beépülveimitálja a felhasználói cseleket.

Natalia Rulyova és Hannah Westley kutatásai szerint a felhasználói preferenciák élén a személyes hírek állnak, ezt követik a helyi hírek, a hiperlokális, majd a nemzeti hírek, aztán a szórakozás és a celebekról szóló hírek (Rulyova és Westley 2017: 1000). Következésképpen az önmagukat semleges tartalomszolgáltatóként beállító, de egyre inkább elsődleges hírforrássá váló közösségi oldalak, mint a Facebook és a YouTube potenciálisan alkalmasak arra, hogy felhasználóikat a saját közegükben manipulálják. A hoaxok partizán módon a webkettes közegekben vannak elhelyezve, melyek népszerúségérôl maguk a felhasználók gondoskodnak. Az álcivil újságírás érzelemorientált videói látszólag spontán módon terjednek a web 2.0-es közösségekben mémként, valójában azonban manipulatív módon szerkesztettek. Az eredeti felvételekböl egyes elemeket kiemelnek, másokat elhallgatnak, a „Két Perc Gyúlölet” orwelli maximáját mozgatják, a hírfolyamban történő megjelenítések a mikrotargetálás érdekében professzionális szintú adatelemzôi tevékenység eredményei (mint azt a Cambridge Analytica cég szerepe mutatja), a propagandaoldalakat a civil újságírás köntösébe rejtik, a GONGO (kormányzat által szervezett nem kormányzati szervezet) taktikáját alkalmazzák stb. Ennek legeklatánsabb példája, hogy amerikai hivatalos vizsgálatok szerint az orosz állam a dezinformációs tevékenységeket a 2016-os amerikai elnökválasztás során névleg nem állami szereplôknek (GONGO), a szentpétervári Internet Research Agency-nek szervezte ki, mely a civilség álarcában és a célzott hirdetés (mikrotargetálás) módszerét kihasználva 3300 hirdetést vásárolt a Facebookon és az Instagramon (hírfolyamban történô megjelenítések), és több milliónyi, választással kapcsolatos manipulatív posztot helyezett el a Twitteren, hogy polarizálják („Két Perc Gyúlölet”) a szavazásra jogosultakat (Bolcsó 2018).

Miközben azonban a 2016-os amerikai elnökválasztás vesztesei Donald Trump megválasztását az önbecsapás régi önvédelmi placebójaként - kizárólagosan vagy döntôen a fake news-nak és a Facebook algoritmusainak tulajdonítják, elmulasztják figyelembe venni a kulturális-társadalmi tényezôket. Egyrészt az álhírek kevésbé változtatták meg a 2016-os amerikai elnökválasztás végeredményét, mivel kimutatható hatásuk kisebb volt, mint amennyivel Trump győzelmet aratott a kulcsfontosságú államokban (Allcott és Gentzkow 2007: 232). Amint azt Debord és Baudrillard a „spektákulum társadalma”, illetve a „szimulákrum elsôbbségének” leírásánál fôként 
az USA-ra utalva megfogalmazta, az élet valamennyi színtere a szórakozás és a látványosság hiperreális világa alapján szerveződik. Aligha véletlen, hogy 9/11 terrortámadása a hollywoodi látványfilmek logikája alapján volt megkomponálva (látványosság, amely vizuálisan - szó szerint „nagyot üt”; a második gép késôbb száll bele a déli toronyba, hogy a televíziótársaságoknak legyen idejük kivonulni; a bábeli torony bibliai allúziója; hőskultusz stb.), és az amerikai katasztrófafilmek (Az elnök különgépe, Deep Impact, Armageddon, Godzilla stb.) forgatókönyve szerint íródott.

Mármost, amikor a pankrátori mutatványokban (errôl átfogóan: Kasnyik 2017) részt vevő Trump a valóságshow-k világa alapján szervezi meg magát, vagy tudatosan imitálja a Clint Eastwood által játszott westernhôsök mozdulatait és mimikáját (fegyvert imitáló mutatóujj, macho testtartás, szigorú tekintet, szájcsücsörítés), a politikát a spektákulum, a sztárság és a bulvár irányába mozdítja el. Miközben a paródiát de Certeau a gyengék fegyvereként tételezi, Trump az NBC Saturday Night Live címú talk-show-jának 2015-ös adásában táncikálásával személyesen parodizálta a kanadai rappernek, Drake-nek a Hotline Bling címú számához készített klipjét, így többszörösen is felforgatta a stratégia és a taktika viszonyát (Trump táncát lásd az SNL alábbi videójában 1:32 perctől). Nem a hatalmi hierarchia alján lévô átlagember, hanem az erôs nyúlt a gúny és a komédia döntôen a civilek szférájához tartozó eszközéhez, s az idegen erôforrást saját imázsának építésére használta fel. Késôbb persze az ezekből készült felhasználói remixek és mémek hatékonynak bizonyultak Trump politikai kampányában, mint amilyenek a $M A G A$ [Make America Great Again] Dance videók, melyek duplacsavarral a paródia paródiái. Merkovity Norbert az önmarketingnek és a politikának ezt a korántsem új, de új szintre emelt ötvözetét a „figyelemalapú politika” címszavával illeti (Merkovity 2016: 7). A népszerúségét a látványosságok és a szórakoztatás alapján megszervezô trumpizmus tehát nem zárvány, mindig is bele volt kódolva az amerikai kultúrába, szervesen következik belóle.

\section{A kereskedelmi modellek politikai újrahasznosítása}

Abban a jelenségben, amely fake news-ként és posztigazságként lett ismeretes a 2016-os amerikai elnökválasztást követôen, általánosan megfigyelhetố tendencia a politika marketingalapú megtervezése. A videoblog és a propaganda álcivil taktikája azonos logikára jár, ami szükségessé teszi a kettô közötti összefüggés vizsgálatát.

A vlog esetében az amatôrség maszkja a kereskedelmi célokat hivatott leplezni, míg az álhírek esetében a szervezett politika alkalmazza a kicsik taktikáját. Ennélfogva a kereskedelmi módszerek a politikai kommunikáció eszköztárává váltak. A bombasztikus hírek tôkésítésére épülô sárga újságírás, a szórakoztatás felé elmozduló infotainment, a word-of-mouth (szájpropaganda) marketingtechnikát kiaknázó churnalism, vagyis a híreknek a hitelesség ellenôrzése nélküli megosztása (Johnston és Forde 2017: 943-946.), a terjesztés önkéntes voltát célzó vírusmarketing, a kicsik certeau-i taktikáját alkalmazó gerillamarketing, az alulról kiinduló kezdeményezés álarcába bújó astroturfing egy irányba mutat. A felhasználókat pszichológiai profilok alapján csoportosító Cambridge Analytica és a politikai hirdetéseket ezek alapján megtervező kampánystábok lényegében a Facebook eredetileg kereskedelmi célokra hasznosított adatgyüjtéseit terjesztették ki 
a politikára. Az államok szolgálatába szegôdô hackerek az információszabadságra épülô hackeretikát forgatták ki. A saját állampolgárait vizuálisan és nagy mennyiségú adat birtokában szemmel tartó kínai államapparátus, amely az ún. társadalmi kreditrendszerrel ijesztố közelségbe hozza az orwelli disztópiát, szintén a web 2.0 modelljeit hasznosította újra politikai célokra. ${ }^{[11]} \mathrm{A}$ megfigyelés a CCTV-k (zártkörú televíziós láncok) mellett (sôt egyre inkább: helyett) a felhasználói tevékenységeket a bármely emberi kémhálózatnál összehasonlíthatatlanul eredményesebben követô adatelemezésre helyezôdik át: a panoptikus láthatóságot a big data panoptikuma váltja fel. Ahogyan a videoblogok esetében gyakran nehéz különbséget tenni az amatốr és a professzionális tartalom között, úgy a civil újságírás eredeti eszméjét is kifordította a certeau-i taktikát kisajátító trollkodás és álhírgyártás.

Nem kellene persze rácsodálkoznunk a meleg víz újbóli feltalálására. Egy médium egymással gyökeresen szemben álló használatmódját Natalie Zemon Davis kimutatta már a könyvkiadás 16. századi francia gyakorlatában is, amikor egymással párhuzamosan állapította meg az egyházi tudásmonopólium csökkenését („A nyomtatás egyrészt lerombolhatja a tudás és a szerzôség hagyományos monopóliumait”) és a kisemberek engedelmességre való nevelésének gyakorlatát („Ugyanakkor a népi gondolkodás ellenôrzésének újfajta módszereit is megteremtheti”) (Davis 2001: 197). A webkettő álcivil politikái persze nemcsak felülról szervezettek, hanem a megosztások révén a laikus maga is terjesztô, sốt akár alkotó is. A lapos föld híveinek webkettes tartalmai, a DHMO (a dihidrogén-monoxid, vagyis a víz) veszélyességét állító és annak betiltásáért harcoló videók és egyéb konspirációs teóriák nem, vagy nemcsak intézményesen szervezettek, hanem rizomatikusak is. A könyv történetéhez hasonlóan a népi web 2.0 segítségével is egymással párhuzamosan épülnek ki a centralizáció és decentralizáció, az információszabadság és a megfigyelóállam struktúrái, ami, persze, a webkettes ideák élő cáfolata.

\section{Mind meghalunk?}

Szinte valamennyi jelentôs amerikai elnök politikai sikerét egy újonnan feltalált kommunikációs médium segítette: Abraham Lincoln az amerikai polgárháborúban az információtovábbítást meggyorsító távíró segítségével került fölénybe a déliekkel szemben, „kandalló melletti csevegéseiben” Theodore Roosevelt a rádiót használta a háborúellenes közhangulat megfordításához, sikerét John F. Kennedy részben a televíziós megjelenések úttörő felismerésének köszönhette, Bill Clinton elsô elnökválasztási kampánya a világhálónak tulajdonított kiemelt jelentôséget, Barack Obama a Facebookot használta ki, míg Donald Trump twitteres bejegyzéseirốl híresült el. Mindebból a technológiai determinizmus atyjával, Harold Innissel szólva azt az elvet párolhatnánk le, hogy minden egyes médium elfogult, valamilyen társadalmikulturális változást lehetôvé tesz, amiból nála az a sarkos megállapítás következik, hogy a médiumok birodalmakat buktathatnak meg (Innis 2011: 7-29.). E csábító elméleti konstrukció ellenére sem gondolom, hogy az új kommunikációs formák, köztük a web 2.0, önmagukban fialnának demokráciát vagy autoriter rendszert. Noha a médiumok nem semlegesek és nem 
ártatlanok, de technikai determinizmus helyett inkább egyes folyamatok felgyorsítását teszik lehetôvé.

A web 2.0 önmagában nem változtat meg világokat, de katalizálja a figyelemorientációra épülô populáris kultúrát és a szenzációra épító populizmust. Ez a folyamat nem vagy nem kizárólag felülrôl szervezett, nem függetleníthetô a „gyengék” alsó szintjeitôl. A standardizáció, a centralizáció, a fake news, a populizmus „taktikai stratégiái” ugyanis aligha kerülhettek volna az érdeklôdés homlokterébe az „ötödik hatalom” felemelkedése, azaz a tömegek részvétele nélkül. A populista politikák, az elit-, tudomány- és értelmiségellenesség minden bizonnyal összefüggésben áll az amatôrök, az „ötödik hatalom” emancipációjával. A web 2.0 ideológiájában (Gerencsér 2019) a sokaság emancipációját zászlajára túzô újbaloldal nem nézett komolyan szembe azzal, hogy az „elnyomottak” nagyon gyakran magukat nyomják el, noha hegemóniaelméletében éppen egy neomarxista filozófus, Antonio Gramsci fogalmazta meg, hogy a domináns politika a többség jóváhagyása segítsége nélkül nem alakulhat ki (Gramsci 1974). A web 2.0 ideológiái azonban nem vették figyelembe, hogy a a popularizálódás a kereskedelemben és a populizmus a politikában nem ok, hanem okozat. A web 2.0 nem az utópiák ideális világa felé vezetett, hanem mind a videoblog, mind a civil video-újságírás esetében egyszerre termelt ki egymással gyökeresen ellentétes folyamatokat. Walter Benjamin a 20. században a kultúra átalakulását az auratikus jelleg felszámolódásában látta (Benjamin 2003). Helyére a 21. században az információs monopóliumok radikális felszámolódása, az infokalipszis lépett.

\section{Jegyzetek}

1. Gerencsér Péter: Bevezetés a web 2.0 fogalmaiba és ideológiáiba. Lásd az Apertúra jelen számában.

2. Részletesebben: The Most Popular Types of YouTube Videos. Mediakix.com. 2018. április 16. (frissitve) http://mediakix.com/2016/02/most-popular-youtube-videos/\#gs.wIn3Pfw (utolsó letöltés dátuma: 201811-04)

3. A kettổ közötti határ elmosódását bôvebben tárgyalja Glózer Rita Túl (?) a részvételi kultúrán címú tanulmányának „Amatốrök és profik” címú fejezete az Apertúra jelen számában.

4. Például: Mattherw: https://www.youtube.com/watch?v=3O4GJoaQpQs. FanMadeMaker: https://www.youtube.com/watch?v=KouU6byxJ_4 (utolsó letöltés dátuma: 2019-02-04)

5. Elviszlek magammal - Szirmai Gergely. WMN Magazin, 2018. október 3. https://www.youtube.com/watch?v=x80Iij18m8g (utolsó letöltés dátuma: 2018-11-04)

6. A dal elôször 2010. december 24-én jelent meg az interneten. Angol feliratozással lásd: https://www.youtube.com/watch?v=IeGlj7OouR0

7. Azt, hogy ez az analógia nem esetleges, mutatja, hogy maga az „Arab Tavasz” elnevezés is „A Népek Tavaszának" titulált 1848-as forradalmak mintájára képzôdött meg.

8. A címbeli „Járulékos gyilkosság” a háború emberi és anyagi áldozatainak eufemisztikus és cinikus elnevezésére, a ,járulékos veszteségre" (collateral damage) rímel.

9. Nem egészen tisztázott Assange viszonya Oroszországgal, ide értve Hillary Clinton emailjeinek a 2016-os amerikai elnökválasztási kampány hajrájában való kiszivárogtatásában játszott feltételezett szerepét is (Graham 2018), az azonban bizonyítást nyert, hogy az Ecuador londoni nagykövetségén menedéket találó férfit titokban Oroszországba akarták csempészni, aminek kapcsán persze megfogalmazódik a kérdés, 
hogy ez miért állt a Kreml érdekében (Kirchgaessner et al. 2018).

10. Korábban ezt a kérdést a náci animációs filmek kontextusában részletesebben tárgyaltam. Lásd a Háziasitott Miki egér címú fejezetet: Gerencsér 2012.

11. A sidney-i székhelyú ABC News televíziós csatornának a kínai társadalmi kreditrendszerról (Social Credit System) készült Exposing China’s Digital Dystopian Dictatorship címú 2018-as dokumentumfilmjét lásd: https://www.youtube.com/watch?v=eViswN602_k

\section{Irodalomjegyzék}

- Allcott, Hunt és Gentzkow, Matthew: Social Media and Fake News in the 2016 Election. Journal of Economic Perspectives, 31 évf. (2017) 2. sz. 211-236. https://doi.org/10.1257/jep.31.2.211

- Barabási-Albert László: Behálózva. A hálózatok új tudománya. Budapest, Helikon, 2016.

- Benner, Jeffrey: He's the Real Tourist Guy. Wired, 2001. november 20. URL: https://www.wired.com/2001/11/hes-the-real-tourist-guy/ (utolsó letöltés dátuma: 2018-11-04)

- Bolcsó Dániel: Most akkor az oroszok koronázták meg Trumpot vagy nem? Index.hu, 2018. február 26. URL: https://index.hu/tech/2018/02/26/trump_oroszorszag_valasztasi_beavatkozas_mueller_vadirat_internet_rese (utolsó letöltés dátuma: 2018-11-04)

- Bourdieu, Pierre: Az újságírás hatalma. Részlet. In Angelusz Róbert, Tardos Róbert és Terestyéni Tamás (szerk.): Média - nyilvánosság - közvélemény. Szöveggyújtemény. Budapest/Pécs, Gondolat Kiadó - PTE BTK Kommunikáció- és Médiatudományi Tanszék, 2011. 105-113.

- Burgess, Jean és Green, Joshua: The Entrepreneurial Vlogger: Participatory Culture Beyond the Professional - Amateur Divide. In Snickars, Pelle és Vonderau, Patrick (szerk): The YouTube Reader. Stockholm, National Library of Sweden, 2009. 89-107.

- Cattani, Razzia: Egy magyar turista kalandjai a cybertérben. Index, 2001. november 14. URL: https://index.hu/tech/net/realtouristg/ (utolsó letöltés dátuma: 2018-11-04)

- Certeau, Michel de: A cselekvés múvészete. Ford. Sajó Sándor - Szolláth Dávid - Z. Varga Zoltán. Budapest, Kijárat, 2010.

- Csigó Péter: A konvergens televiziózás. Web, tv, közösség. Budapest, L'Harmattan, 2009.

- Daubs, Michael S.: Subversive or Submissive? User-Produced Flash Cartoons and Television Animation. Animation Studies Online Journal - Animation Studies, 5.51 (2010). URL: http://journal.animationstudies.org/wp-content/uploads/2011/02/ASVol5Art5MDaubs.pdf (utolsó letöltés dátuma: 2018-11-04)

- Dorfles, Gillo: A TV mint egy új vizuális expresszivitás csatornája. Ford. Beke László. In Bán András - Beke László (szerk.): Videómüvészet. A videó világa. Budapest, Népmúvelődési, 1983.

- Epstejn, Mihail: Az orosz posztmodern értelme és eredete. Ford M. Nagy Miklós. In uô: A posztmodern és Oroszország. Budapest, Európa. 2001. 5-69.

- Fisher, Alyssa és Ha, Louisa: What Do Digital Natives Watch on Youtube? In Ha, Louisa: The Audience and Business of YouTube and Online Videos. Lanham/Boulder/New York/London, Lexington Books, 2018. 29-58.

- Michel Foucault: Felügyelet és büntetés: A börtön születése. Ford. Fázsy Anikó - Csûrös Klára. 
Budapest, Gondolat, 1990.

- Garcia, David - Lovink, Geert: A taktikus médiumok ábécéje. Ford. Gyukits Gábor. In Sugár János - Ivacs Ágnes (szerk.): Buldózer. Médiaelméleti antológia. Budapest, Media Research Alapítvány, 1997. URL: http://mek.oszk.hu/00100/00140/html/ (utolsó letöltés dátuma: 201811-04)

- Gerencsér Péter: McLaden \& Tali Wars. Képi cenzúra és paródia a szeptember 11-i terrortámadások után. Vár Ucca Múhely, 35.3 (2003), 46-60.

- Gerencsér Péter: A propagandától a metanyelvi önreflexióig. A cseh animációs film politikai hagyományáról. Apertúra, 2012. nyár. URL: http://apertura.hu/2012/nyar/gerencser-apropagandatol-a-metanyelvi-onreflexioig-a-cseh-animacios-film-politikai-hagyomanyarol (utolsó letöltés dátuma: 2018-11-04)

- Gerencsér Péter: A mediatizált láthatatlansága. A látványtársadalom kritikája az internetes katasztrófahumorban 9/11 után. Vár Ucca Múhely, 46. 4. (2014), 16-31. URL: https://issuu.com/mveszetekhaza/docs/varucca-46-beliv (utolsó letöltés dátuma: 2018-11-04)

- Gerencsér Péter: Bevezetés a web 2.0 definícióiba és ideológiáiba. Apertúra, 2019. tél.

- Glózer Rita: Túl(?) a részvételi kultúrán. Apertúra, 2019. tél.

- Graham, David A.: Is WikiLeaks a Russian Front? The Atlantic, 2018. november 29. URL: https://www.theatlantic.com/politics/archive/2018/11/wikileaks-trump-mueller-roger-stonejerome-corsi/576940/ (utolsó letöltés dátuma: 2019-01-04)

- Gramsci, Antonio: Levelek a börtönböl. Ford. Gábor György - Zsámboki Zoltán. Budapest, Kossuth, 1974.

- Greenberg, Clement: Avantgarde és giccs. In Józsa Péter (szerk.): Múvészetszociológia. Válogatott tanulmányok. Budapest, Közgazdasági és Jogi, 1978. 93-103.

- Greenberg, Clement: Avantgarde és giccs. In Gillo Doerfles: A giccs. A rossz izlés antológiája. Ford. Schéry András. Budapest, Gondolat, 1986. 109-118.

• Gunning, Tom: „Nagyon finom teveszőr ecsettel rajzolták”. A filmes múfajok eredetei. Ford. Kaposi Ildikó. In Vajdovich Györgyi (szerk.): A kortárs filmelmélet útjai. Budapest, Palatinus, 2004. 273-291.

- Hall, Kimberly Ann: The authenticity of social-media performance: lonelygirll5 and the amateur brand of Young-Girlhood. Women \& Performance: A Journal of Feminist Theory, 25. 2 (2015), 128-142. https://doi.org/10.1080/0740770X.2015.1057011

- Innis, Harold A.: A kommunikáció részrehajlása. In Angelusz Róbert, Tardos Róbert és Terestyéni Tamás (szerk.): Média - nyilvánosság - közvélemény. Szöveggyújtemény. Budapest/Pécs, Gondolat Kiadó - PTE BTK Kommunikáció- és Médiatudományi Tanszék, 2011. 7-29.

- Jenkins, Henry: Textual Poachers: Television Fans and Participatory Culture. New York, Routledge, 1992.

- Jenkins, Henry: Why Participatory Culture Is Not Web 2.0: Some Basic Distinctions. 2010. május 23. URL: http://henryjenkins.org/blog/2010/05/why_participatory_culture_is_n.html (utolsó letöltés dátuma: 2018-11-04)

- Johnston, Jane és Forde, Susan: Churnalism: Revised and revisited. Digital Journalism, 5. 8 (2017), 943-946. DOI: 10.1080/21670811.2017.1355026 https://doi.org/10.1080/21670811.2017.1355026 
- kasnyikm [Kasnyik Márton]: Trump igazi ideológiája: a pankráció. 444.hu, 2017. augusztus 31. URL: https://444.hu/2017/08/31/trump-igazi-ideologiaja-a-pankracio (utolsó letöltés dátuma: 2018-11-04)

- Kirchgaessner, Stephanie - Collyns, Dan - Harding, Luke: Revealed: Russia's secret plan to help Julian Assange escape from UK. The Guardian, 2018. szeptember 21. URL: https://www.theguardian.com/world/2018/sep/21/julian-assange-russia-ecuador-embassylondon-secret-escape-plan (utolsó letöltés dátuma: 2018-11-04)

- Khamis, Sahar: The Role of the Media in Arab Transitions: How 'Cyberactivism' is Revolutionizing the Political and Communication Landscapes. In IEMed Mediterranean Yearbook, Barcelona, European Institute of the Mediterranean, 2013. 55-59.

- Kozloff, Sarah: Narrációelmélet és televízió. Ford. Gollowitzer Dóra Diána. In Füzi Izabella (szerk.): Verbális és vizuális narráció. Szöveggyújtemény. Szeged, Pompeji, 2010. 7-38.

- Krauss, Rosalind: Videó: a nárcizmus esztétikája. In Bán András - Beke László: Videómúvészet. A videó világa. Budapest, Népmúvelôdési Intézet, 1983. 46-51.

- Kunczik, Michael: A demokratikus újságírás. Médiakutató, 2.3 (2001), 7-21.

- Manovich, Lev: Az adatbázis mint szimbolikus forma. Ford. Kiss Julianna. Apertúra, 2009. ósz. URL: http://apertura.hu/2009/osz/manovich (utolsó letöltés dátuma: 2018-11-04)

- Manovich, Lev: A mindennapi (média) élet gyakorlata. Ford. Mátyus Imre. Apertúra, 2011. tavasz. URL: http://apertura.hu/2011/tavasz/manovich (utolsó letöltés dátuma: 2018-11-04)

- Margócsy István: Petôfi Sándor. Kisérlet. Budapest, Korona, 1999.

- Merkovity Norbert: A figyelemalapú politika és Donald Trump. Médiakutató, 2016. ôsz-tél. 7-16.

- Riaz, Saqib: Role of Citizen Journalism in Strengthening Societes. Margalla Papers, 2011. 109128.

- Richardson, Joanne: A taktikai média nyelvezete. Ford. Erhardt Miklós. C3. [2002] URL: http://www.c3.hu/ ligal/ManaJoannel.htm (utolsó letöltés dátuma: 2018-11-04)

- Rulyova, Natalia és Westley, Hannah: Changing News Genres as a Result of Global Technological Developments. Digital Journalism, 5.8 (2017), 986-1005. https://doi.org/10.1080/21670811.2017.1351882

- Tófalvy Tamás: A digitális jó és rossz születése. Technológia, kultúra és az újságírás 21. századi átalakulása. Budapest, L'Harmattan, 2017. 
(C) Apertúra, 2019. tél | www.apertura.hu

webcím: https://www.apertura.hu/2019/tel/gerencser-civil-a-felvevogeppel-a-certeau-i-taktika-

kisajatitasa-a-vlogokban-es-a-civil-ujsagirasban/

https://doi.org/10.31176/apertura.2019.14.2.4

(Q)opertúro 